Image 2:022

\title{
Pneumothorax and Subcutaneous Emphysema. When Assessing Chest Tube Placement
}

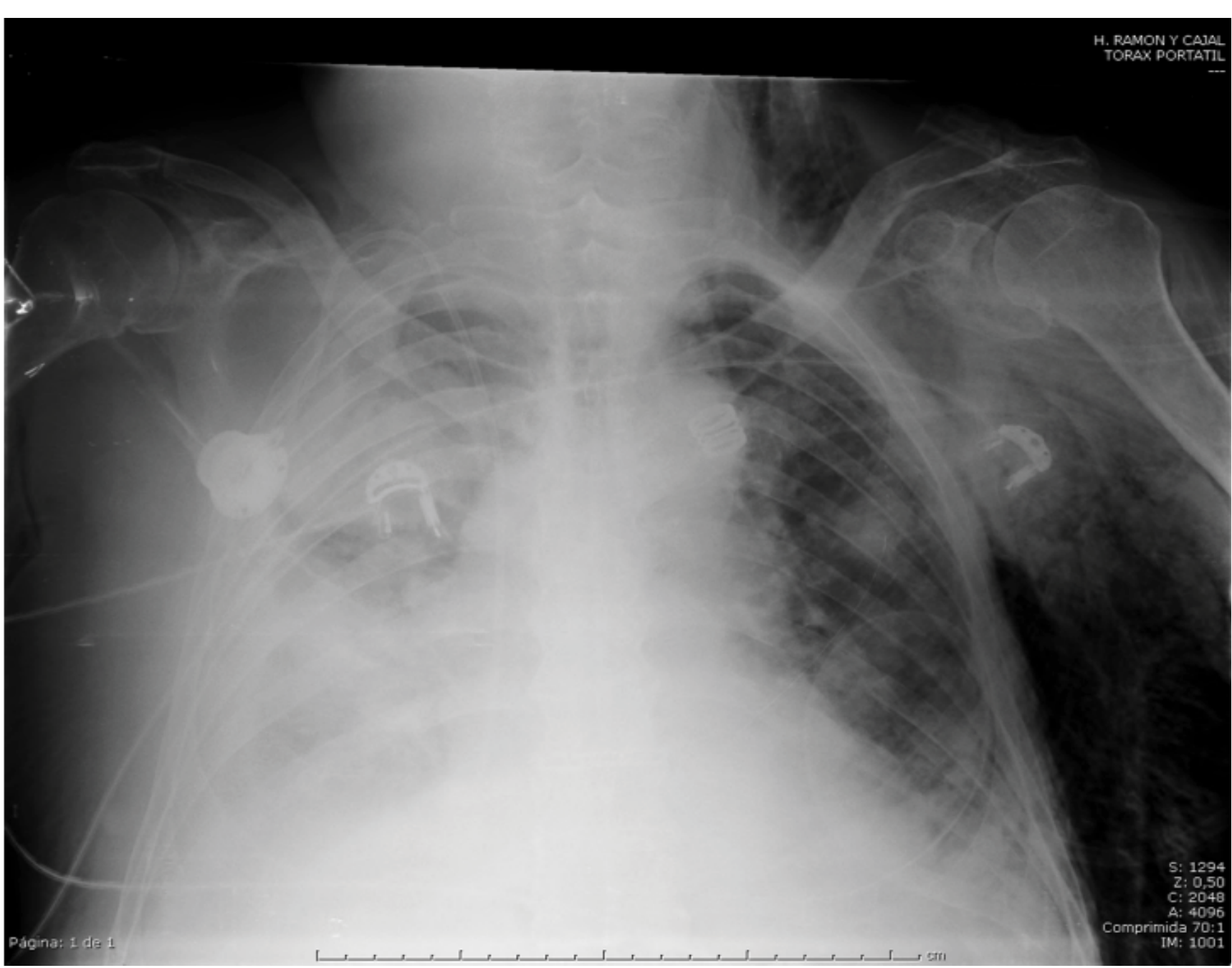

Figure 1: Pneumothorax and subcutaneous emphysema

\section{Keywords}

Pneumothorax, Subcutaneous emphysema, Chest tube

\section{Information}

Ana Patricia Ovejero Díaz*, Gemma María Muñoz Molina and Ana Paz Valdebenito Montecino

Department of Thoracic Surgery, Hospital Ramón y Cajal, Spain

${ }^{*}$ Correspondence: Ana Patricia Ovejero Díaz, Degree in Medicine and Surgery, Department of Thoracic Surgery, MIR, Hospital Ramón y Cajal, Carretera Colmenar Viejo km 9100, 28034, Spain, E-mail: futmed@hotmail.com Tel: 687653885.
Citation: Díaz APO, Molina GMM, Montecino APV (2016) Pneumothorax and Subcutaneous Emphysema. When Assessing Chest Tube Placement. Clin Med Img Lib 2:022

Published: January 08, 2016

Copyright: (C) 2016 Díaz APO, et al. This is an open-access content distributed under the terms of the Creative Commons Attribution License, which permits unrestricted use, distribution, and reproduction in any medium, provided the original author and source are credited.

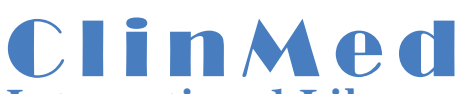

International Library 
Subcutaneous emphysema occurs when air gets into tissues under the skin. It occurs mainly in the neck, chest and face when air travel to these areas of the chest cavity through the fascia. Introducing the chest radiograph of a 73 year old male diagnosed with chronic pericardial effusion mass, intervened on a scheduled basis for pericardial window, and in the immediate postoperative period presents important in left chest subcutaneous emphysema associated with desaturation and tachycardia. Suspecting possible pneumothorax that can not be clearly distinguished in the test image, and the likely need for intubation to the serious clinical condition, chest tube placement, which successfully produces clinical improvement and patient decide. The main causes that we suspected in a subcutaneous emphysema are pneumothorax, broken tree traqueobronquial1, esophageal rupture, necrotizing infections and dental procedures using air comprimido2 elements, and to the possible need for applying positive pressure to the patient, as in this case , we will place a chest tube though not clearly distinguish the camera radiographic pneumothorax.

\section{References}

1. P Vila Caral, R Castillo Omedas, C Llubiá Maristany (2010) Tracheal laceration during intubation with a Frova introduce. Revista Española de Anestesiología y Reanimación 57: 599-602.

2. Rodríguez-Arrondo Franciscoa, Arévalo Sarab, Camino Xaviera, Wichmanna Miguel Ángela (2003) Neumonía necrosante comunitaria asociada a bacteriemia y focos sépticos metastásico. Enfermedades infecciosas y microbiología clínica 21: 211-213. 